DOI: 10.17805/trudy.2016.3.7

\title{
ТЕМА ЩЕДРОСТИ В РАННИХ ПОХВАЛАХ ВЕЛИКОМУ КИЕВСКОМУ КНЯЗЮ ВЛАДИМИРУ СВЯТОСЛАВИЧУ
}

\author{
В. М. Кириллин \\ (Московский гуманитарный университет)
}

Аннотация: В статье на основе сопоставительного анализа древнейших литературных характеристик великого Киевского князя Владимира Святославича (X-XI вв.) выявляются особенности официального церковного и неофициального народного отношения к нему как к исполнителю христианской заповеди о милосердии.

Ключевые слова: князь Владимир Святославич; Древняя Русь; история русской литературы; литературный этикет; русский эпос; русская летопись

\section{THE THEME OF GENEROSITY IN EARLY ENCOMIA TO GRAND PRINCE VLADIMIR SVIATOSLAVICH OF KIEV}

\author{
V. M. Kirillin \\ (Moscow University for the Humanities)
}

Abstract: The article provides a comparative analysis of the earliest literary portrayals of grand prince Vladimir Sviatoslavich, outlining both the official church image of Prince Vladimir and the popular view of him as endowed with the Christian virtue of mercy.

Keywords: prince Vladimir Sviatoslavich; Old Rus'; history of Russian literature; literary etiquette; Russian epic; Russian chronicle (letopis')

Слава великого Киевского князя Владимира Святославича началась еще при его жизни. Несомненно, современники ценили этого правителя за разные его личностные достоинства. Но смерть князя (в 1015 г.) стала началом многовековой и благодарной памяти о нем в народном сознании. Уже в XI в. появляются первые сохраненные древнерусской книжностью сказания, описывающие и восхваляющие его деяния, - «Слово о Законе и Благодати» митрополита Илариона ${ }^{1}$, «Память и похвала Владимиру» Иакова

\footnotetext{
${ }^{1}$ «О Законе, Моисеом данеем, и о Благодети и Истине, Исусом Христом бывшии и како Закон отиде, Благодеть же и Истина всю землю исполни, и вера въ вся языкы простреся и до нашего языка Рускаго, и похвала кагану нашему Влодимеру, от негоже крещени быхом, и молитва к Богу от всеа земля нашеа» (Библиотека литературы Древней Руси,1997: 26-61). Здесь и далее древнерусский текст воспроизводится орфографически упрощенно.
} 
Мниха, летопись (Кириллин, 2014: 32). Бесспорно, в них отразилось устное предание, живые отголоски которого, правда, были печатно зафиксированы только при начале изучения русского эпоса в конце XVIII в. (Азадовский, 1958: 64-68, 84-86, 102-104; Зуева, 2001: 105-106). Как можно думать, личность Владимира Святославича остается привлекательной и для какойто части современного общества (Замостьянов, 2015: Электр. ресурс).

Что касается древности, то уже в первых воспоминаниях о знаменитом князе выделились три главных темы: Владимир - креститель Руси, равноапостольный князь; Владимир - идеальный государственный деятель; Владимир - совершенный исполнитель христианской заповеди о милосердии. Именно последняя тема и является предметом внимания настоящей статьи.

Сравнение выше указанных литературных произведений обнаруживает динамику развития этой темы в сознании русского общества XI - начала XII в. Особенно показательны при этом фрагменты панегирического характера.

Наиболее ранним является текст «Слова о Законе и Благодати» митрополита Илариона , возникший примерно на рубеже 30-40-х гг. XI в. Здесь, в разделе, посвященном похвале Владимиру Святославичу, о нем сообщается следующее:

«К сему же кто исповесть (поведает. - В. К.) многыа твоа нощныа милостыня и дневныа щедроты, яже (которые. - В. К.) к убогыим творяаше, к сирыим, к болящиим, к должныим, к вдовам и к всем требующим милости? Слышал бо бе глагол, глаголаный (слово, сказанное. - В. К.) Даниилом к Науходоносору: «Совет мой да будет ти годе (угоден. - В. К.), царю Науходоносоре, грехы твоа мшюстинями оцести (милостями очисти. - В.К.) и неправды твоа - щедротами нищиих» (Дан. 4: 24). Еже слышав ты, о честниче, не до слышаниа стави глаголаное (не довольствовался только слышанным. - В. К.), но делом сконча (но на деле исполнил. - В. К.), просящиим подаваа, нагыа одевая (нагих. - В. К.), жадныа и алчныа (жаждущих и алчущих. - В. К.) насыщая, болящиим всяко утешение посылаа, должныа искупая (должников выкупая. - В. К.), работныим (рабам. - В. К.) свободу дая. Твоа бо щедроты и милостыня и ныне в человецех поминаемы суть (поминаются в народе. - В. К.), паче же пред Богом и ангелом (ангелами. - В. К.) его. Ея же ради доброприлюбныа Богом (благоугной. - В. К.) милостыня, много дръзновение имееши к нему (перед ним. - В. К.), яко присный (ис-тинный. - В. К.) Христов раб»

(Библиотека литературы Древней Руси, 1997: 48).

Судя по содержанию этого пассажа о благотворительном служении Владимира Святославича, панегирист довольно жестко следует отвлеченному литературному этикету (Лихачев, 1979: 80-102), стремясь к иконной идеализации своего героя. Соответственно, он не столько констатирует прижизненное милосердие киевского правителя, согласующееся с заве- 
том ветхозаветного пророка Даниила², сколько говорит о крестителе Руси как о личности, ниспосылающей людям свою помощь по смерти: с небес, от Бога. То есть для него здесь в большей степени важно патронажное значение Владимира как небесного заступника за Русскую землю. Но при этом он весьма номинативен, то есть предпочитает устоявшиеся, традиционные констатирующие словесные формулы описательным деталям и подробностям.

В конце своей речи Иларион еще раз и вновь номинативно отмечает попечительность крестителя Руси о своем народе, используя форму богослужебного славословия:

«Ты... милостынею яко гривною и утварью златою красуяся (ук-рашен.

- В. К.). Ты бе (был. - В. К.), честная главо, нагыим одение (нагим одеяние. - В. К.), ты бе алчныим кормитель (алчущим насыщение. - В. К.), ты бе жаждющим утробе ухлаждение (охлаждение их утробы. - В. К.), ты бе вдовицам помощник, ты бе странныим покоище (странникам обиталище. - В. К.), ты бе бескровным покров, ты бе обидимым заступник, убогыим (бедным. - В. К.) обогащение»

(Библиотека литературы Древней Руси, 1997: 52).

Но на сей раз, как видно, восхваляется покровительственная забота о людях со стороны крестителя Руси в пору его именно земного существования.

У следующего панегириста, Иакова Мниха, в «Памяти и похвале» ${ }^{3}$, составленной не позднее конца 80-х гг. XI в., теме милосердия и щедрости великого Киевского князя Владимира Святославича, уделено значительно больше внимания, и раскрывается она более пространно, изобразительно и с иными акцентами.

Прежде всего, Иаков настоятельно воспевает именно прижизненную щедрость крестителя Руси, - мотив, как уже отмечено, слабо и без конкретизирующих разъяснений прозвучавший у Илариона:

«И три трапезы [Владимир] поставляше (устраивал. - В. К.): первую митрополиту с епископы, и с черноризце, и с попы; вторую нищим и убогым; третью собе, и бояром своим, и всем мужем своим»

(Библиотека литературы Древней Руси, 1997: 320).

${ }^{2}$ При этом антитеза «Навуходоносор - Владимир» явственно указывает у него на превосходство последнего, ибо Киевский князь делами милосердия вполне искупил свою дохристианскую греховность перед Богом в противоположность древнему творцу истуканов и разрушителю Иерусалима, который, как известно, хоть и признал в конце жизни величие Единого Творца, и даже от тяжкого недуга безумия исцелился, но ничего не сделал в свое оправдание (Иллюстрированная полная ..., 1891: 498-499; Вихлянцев, 1998: 156-157).

${ }^{3}$ «Память и похвала князю русскому Володимиру: како крестися Володимир, и дети своя крести, и всю землю рускую от конца до конца, и како крестися баба Володимерова Олга преже Володимера. Списано Иаковом мнихом» (Библиотека литературы Древней Руси, 1997: 316-327). 
Другими словами, правитель Киева стремился к социальному распределению своей казны. Важно при этом отметить, что Иаков, указывая на благотворение князя как на особенность его отношения к подвластному ему народу, возможно, подразумевал конкретную культурноисторическую параллель. Во всяком случае, приведенный текст по общему смыслу весьма близок рассказу латинского «Евангелия Псевдо-Матфея» об отце Девы Марии, праведном Иоакиме:

«Был в Иерусалиме человек некий, именем Иоаким из колена Иудо-

ва... Он делил на три части стада свои, имущество свое и все то, чем он владел. И отдавал он одну часть вдовам, сиротам, странникам и бед-ным, другую тем, кто был посвящен на служение Богу, а третью он сохранял для себя и дома своего» ${ }^{4}$

Конечно, категорические утверждения в данном случае неуместны, поскольку указанный апокриф, весьма популярный в средневековой Европе (Древнейшая рукопись относится к X в., см.: Reid, 1913: 607), не сохранен славяно-русской книжностью и, вероятно, не был ей известен. Но подозрение, что Иаков мог быть знаком с преданием о Иоакиме, все же возникает. А если такое подозрение правомерно, то почему бы не думать в данном случае о предлагаемой панегиристом скрытой аналогии, или неявном сопоставлении Владимира с праотцем Иоакимом? Подобный ход мысли тем более оправдан, если учесть, что христианская супруга Владимира, как и супруга Иоакима, именовалась Анной.

У Иакова Мниха, однако, имеется и прямое ретроспективное сопоставление ${ }^{5}$, сопряженное с его стремлением охарактеризовать Киевского князя как благотворящего правителя. Оказывается, по крещении Владимир Святославич:

«Възлюби Аврамово житие (Восхитился жизнью Авраама. - В. К.) и подража (подражал. - В. К.) странолюбию его»

(Библиотека литературы Древней Руси, 1997: 322).

И действительно, согласно библейскому свидетельству, родоначальник евреев Авраам не только с почтением принял явившихся к нему трех чудесных гостей в дубраве Мамре (Быт. 18: 21), но создал, кроме того, прецедент как благодетель, выделив селимскому царю и священнику Мельхиседеку при встрече с ним десятую часть от своего имущества (Быт. 14: 18-19). Вряд ли следует сомневаться, что этой параллелью (напомню, князь Владимир тоже выделил десятую часть от своих доходов

\footnotetext{
${ }^{4}$ Книга о рождении благодатной Марии и детстве Спасителя, написанная по-еврейски блаженнейшим евангелистом Матфеем и переведенная полатински блаженным Иеронимом, пресвитером (Иисус Христос в документах истории, 2001: 183).

${ }^{5}$ О принципе ретроспективной исторической аналогии в древнерусской литературе см.: Каравашкин, 2003: 47-68; Панченко, 2003: 491-534.
} 
на содержание основанной им в Киеве церкви во имя Пресвятой Богородицы) Иаков обозначил такие личностные свойства крестителя Руси, как гостеприимство, милосердие, щедрость.

В «Памяти и похвале» тема благотворения Владимира Святославича раскрывается и прямо, в наглядной конкретике:

«...Боле же всего бяше милостыню творя (творил. - В. К.) князь Володимер. Иже немощныа и старыа не можаху (Когда те немощные и старые, кто не могли. - В. К.) дойти княжа двора и потребу взяти (взять необходимое. - В. К.), то (тогда. - В. К.) в домы им посылаше. Немощным и старым всяку потребу блаженый князь Володимер даяше (давал. - В. К.). И не могу сказати (описать. - В. К.) многыа его милостыня. Не токмо в дому своем милостыню творяше, но и по всему граду, не в Киеве едином, но и по всей земле Руской. И в градех, и в селех, - везде милостыню творяше. Нагыа одевая, алчныя кормя и жадныя напаяя; странныа покоя милостью; церковникы чтя, и любя, и милуя, подавая им требование; нищая, и сироты, и вдовица, и слепыя, и хромыя, и трудоватыя, - вся милуя, и одевая, и накормя, и напаяя. Такоже пребывающу князю Володимеру в добрых делех, благодать (Когда князь Владимир добрые дела совершал, то благодать. - В. К.) Божия просвещаше сердце его и рука Господня помогаше ему»

(Библиотека литературы Древней Руси, 1997: 322).

Несомненно, Иаков Мних в сравнении с Иларионом и конкретнее и эмоционально теплее, хотя и он использует устойчивые выражения. Соответственно, из-под его пера выступает более ярко представимый лик именно жившего на земле доброго правителя, более ясный характер заботившегося о своем народе здесь, в этой жизни, властелина. При этом тема небесного покровительства крестителя Руси своей земле у Иакова, в отличие от «Слова о Законе и Благодати», не получает никакого развития, хотя по ряду признаков видно, что он признавал святость Владимира. Между прочим, в плане «приземленности» его текст представляется идейно конгениальным летописной похвале князю. Так, согласно еще более позднему памятнику - Начальному летописному своду 1093 г., ставшему основой для «Повести временных лет» ${ }^{6}$, Владимир Святославич, счастливо выжив в битве с печенегами, в 996 г., воздвиг:

«...церковь (Преображения Господня. - В. К.) и творяше (устроил. В. К.) празник, варя 300 перевар (наварив 300 мер. - В. К.) меду. И зваше бояры своя, и посадникы, и старейшины по всим градом, и люди многы, и раздаваше 300 гривен убогым (бедным. - В. К.). И празнова князь Володимер ту дний 8, и възвращашется Кыеву (возвратился в Киев. - В. К.) на Успение святыя Богородица, и ту пакы творяше праздник светел, сзываше

${ }^{6}$ «Повесть временных лет черноризца Федосьева манастыря Печерскаго, откуду есть пошла Руская земля... и хто в ней почал первее княжити, и откуду Руская земля стала есть» (Библиотека литературы Древней Руси, 1997: 62-315). 
бещисленое множство народа. Видяше же люди, крестьяны суща (христиане. - В. К.), радовашеся душею и телом. И тако по вся лета творяше (делал постоянно. - В. К.)»

(Библиотека литературы Древней Руси, 1997: 168).

Как видно, свидетельство Иакова относительно щедрости великого господина Киевской Руси в плане интереса к его реальным благодеяниям вполне тождественно повествованию летописи. Однако сравнительно с «Памятью и похвалой» в «Повести временных лет» тема направленных на народ благотворений Владимира Святославича развита еще сильнее. По летописцу, князь - щедрый податель милости, в деяниях которого воплотилась народная мечта о сытом изобилии, справедливом распределении благ и неизбывном празднике:

«Си (Это <заветы Евангелия, а также пророков Давида и Соломона>. - В. К.) слышав, повеле нищю всяку (всякому нищему. - В. К.) и убогу (бедному. - В. К.) приходити на двор на княжь и взимати всяку потребу: питье и яденье (пищу. - В. К.), и от скотнич кунами (из казны деньги. - В. К.). Устрои же се, рек (Устроив же это, сказал. - В. К.), яко “Немощнии, болнии не могут доити двора моего”. Повеле (И приказал. - В. К.) устроити кола (снарядить телеги. - В. К.) и, вьскладываше (наложив на них. - В. К.) хлебы, мяса, рыбы и овощ разноличный и мед в бочках, а в другыхъ квасы, возити по градом, вьпрашающе: “Кде болнии, нищии, не могы ходити?” И тем раздаваху на потребу (раздавали по необходимости. - В. К.). И се же творя (И это делал. - В. К.) людем своим: по вся неделя устави (в течение всей недели велел. - В. К.) на дворе в гридници пир творити и приходити бояром, и гридем, и соцким, и десятником и нарочитым мужем и при князе и без князя. И бываше (бывало. - В. К.) на обеде том множьство от мяс, и от скота, и от зверины, и бяше же изобилью всего (и было все в изобилии. - В. К.)»

(Библиотека литературы Древней Руси, 1997: 168, 170).

Несомненно, данный текст развивает в деталях констатированный еще Иаковом Мнихом факт постоянной прижизненной заботы Владимира Святославича о благополучии своих подданных. Однако летописец текстуально почти независим от «Памяти и похвалы»; скорее всего, он пользовался своими источниками и, бесспорно, представил читателю более живую и зрелищную картину благодеяний крестителя Руси. Скорее всего, оба панегириста опирались на народно-эпическую традицию. Во всяком случае, по наглядности и житейской конкретике и текст Иакова, и текст летописный весьма близки к последней, отраженной, например, в былине «Бой Добрыни с Дунаем»:

«Собирал им ${ }^{7}$ Владимир все почестен пир

Для многих князей, для многих бо́яров,

Да для сильных могучих богатырей,

${ }^{7}$ Добрыне и Дунаю. 
Для всех полениц да преудалыих,

Для всех купцов-гостей торговыих,

Для всех крестьянушек прожиточных,

Да про многих казаков со тиха Дону,

Да про всех-то калик да перехожиих,

Перехожиих калик да переброжиих.

Еще все на пиру тут напивалися,

Еще все на честном пиру наедалися,

Еще все на пиру были пьяны-веселы»

(Библиотека русского фольклора: Былины, 1988: 74-75).

Менее показательной является народная проза, например, сказка «Балдак Борисьевич»:

«В славном городе во Киеве у царя у Владимира собирались князья и бояре и сильномогучие богатыри на почестный пир. Возговорил Владимирцарь таково слово: “Гой есте, мои ребята! Собирайтеся, сокопляйтеся за единый стол!” Собиралися за единый стол, вполсыта наедалеся, вполпитья напивалися...»

(Библиотека русского фольклора: Сказки. Книга 2, 1989: 497)

Все же и здесь запечатлен образ щедрого правителя Русской земли.

Между прочим, в летописи читается также посмертная похвала Владимиру Святославичу (статья в «Повести временных лет» за 1015 г.). И в ней применительно к теме его щедрости различаются государственный и социальный аспекты княжеской попечительской деятельности:

К усопшему «снидошася бе-щисла (сошлось бесчисленное множество людей. - В. К.), и плакашася по немь (оплакивали его. - В. К.), - бояре аки заступника земли их, убозии акы заступника и кормителя»

(Библиотека литературы Древней Руси, 1997: 174).

Больше того, летописец теоретически обосновывает необходимость подобного отношения к народу, находя опору для своего убеждения в Евангелии:

«Сый же умер во исповедании добрем (следуя добру. - В. К.), покааньем расыпа грехы своя, милостнями (покаянием исправив грехи свои и милостыней. - В. К.), иже есть паче всего добрей. “Милостыни бо хощю, а не жертве” (Мф. 9: 13). Милостьни (Милостыня. - В. К.) бо есть всего луче и вышьше, возводящи (возносит она. - В. К.) до самого небеси пред Бог (к Богу. - В. К.)»

(Библиотека литературы Древней Руси, 1997: 174).

${ }^{8}$ Понятно, что в обоих случаях воспроизведена очень поздняя фиксация народного предания и собирательного представления. Но все же корни подобного предания и представления уходят в самую глубь веков. То есть вряд ли можно сомневаться в том, что и в древности Владимир Красное Солнышко рисовался народному воображению примерно так. 
Итак, сравнение древнейших текстов, посвященных восхвалению попечительной заботы великого Киевского князя Владимира Святославича о подданных, обнаруживает различные подходы и отношение к литературному развитию данной темы. Митрополит Иларион как духовник сына Владимира Святославича Ярослава Мудрого и представитель Церкви держался простой - канонически предопределенной и содержательно не развернутой, схематичной - констатации милосердия, благотворительности и щедрости крестителя Руси, отмечая вместе с тем его патронажное служение на небесах. Илариона отличает стремление к созданию иконного образа святого князя. Иаков Мних, скорее всего занимавший низшую ступень в церковной иерархии, был ближе к народной среде и, соответственно, его больше заботило народное представление о том, каким князь был при жизни и чем он был хорош как правитель. Поэтому Иаков, используя детали и подробности, стремился к созданию его живого личностного портрета, но не иконы. Эта же тенденция наблюдается в летописи и былинных источниках. В общем же аксиология всех восхвалителей направлена на идеализацию князя как благоподателя. Только Иларион был больше ориентирован на традиции и идеалы официальной церковной литературы, а Иаков, летописцы и народные сказители - на традиции и идеалы эпической поэзии и прозы. И при этом очевидно, что все они воспринимали власть в лице Владимира Святославича как источник добра и силу, предназначенную для заступнического попечения о народе. В этом, несомненно, выразилось глубоко патриархальное представление о патерналистских функциях власти. Представление, но не идеология, то есть не сложившаяся целостно «система идеалов, ценностей, взглядов и убеждений, посредством которой личность выражает свое отношение как к существующей социальной реальности в целом, так и к конкретным ее аспектам» (Ильинский, 2014: 7-8). В российской культурной традиции, если не говорить здесь о православном вероучении, подобная система будет прокламирована только в XIX в., в знаменитой триаде графа С.С.Уварова «Православие, Самодержавие, Народность» (Доклады министра ..., 1995: 70). Применительно же ко времени появления рассмотренных выше литературных памятников можно говорить лишь о зачатках идеологии и их стихийном воплощении в слове.

\section{СПИСОК ЛИТЕРАТУРЫ}

Азадовский М. К. (1958) История русской фольклористики / под общ. ред. Э. В. Померанцевой. М. : Учпедгиз. 478 с.

Библиотека литературы Древней Руси (1997). Т. 1: XI-XII века. СПб. : Наука. 543 с.

Библиотека русского фольклора: Былины (1988) / сост., вступ. статья, 
подгот. текстов, коммент. Ф. М. Селиванова. М. : Советская Россия. 576 с.

Библиотека русского фольклора: Сказки. Книга 2 (1989) / сост., подгот. текстов, коммент. Ю. Г. Круглова. М. : Советская Россия. 576 с.

Вихлянцев В. П. (1998) Библейский словарь к русской канонической Библии Синодального перевода 1816-76 гг. М. 317 с.

Доклады министра народного просвещения С. С. Уварова императору Николаю I (1995). Публикация М. М. Шевченко // Река времен. Вып. 1. M. C. 68-78.

Замостьянов, А. (2015) Семь художественных воплощений святого равноапостольного князя в многовековой русской литературе [Электронный ресурс] // Год литературы. 20.07. URL: https://godliteratury.ru/publicpost/knyaz-vladimir-v-literature (дата об-ращения: 29.04.2016).

Зуева Т. В. (2001) Былины // Литературная энциклопедия терминов и понятий / глав. ред. и составитель А. Н. Николюкин. М. : Интелвак. 1600 с. Стб. 105-107.

Иисус Христос в документах истории (2001) / сост., статья и комм. Б.Г.Деревенского. СПб. : Алетейя. 545 с.

Иллюстрированная полная популярная Библейская энциклопедия (1891): Труд и изд. архим. Никифора. М. 764 с.

Ильинский И. М. (2014) Воспитание в уважении и любви // Знание. Понимание. Умение. № 2. С. 5-10.

Каравашкин, А. В. (2003) Историческая аналогия в системе универсалий древнерусской литературы: на материале агиографии XIV-XV вв. (к постановке вопроса) // Литература Древней Руси. М. : АСТ. С. 47-68.

Кириллин В. М. (2014) Образ князя Владимира Святославича в ранних древнерусских гомилиях // Древняя Русь: Вопросы медиевистики. №2 (56). С. 32-48.

Лихачев Д. С. (1979) Поэтика древнерусской литературы. Изд. 3-е. М.: Наука. 359 с.

Панченко, О. В. (2003) Поэтика уподоблений (к вопросу о «типологическом» методе в древнерусской агиографии, эпидейктике и гимнографии) // Труды Отдела древнерусской литературы / отв. ред. Д. С. Лихачев. СПб. Т. 54. С. 491-534.

Reid, G. J. (1913) Apocrypha // The Catholic Encyclopedia. Vol. I. New York. P. 600-615.

Кириллин Владимир Михайлович - доктор филологических наук, профессор кафедры журналистики Московского гуманитарного университета. Адрес: 111395, Россия, Москва, ул. Юности, д. 5. Тел.: +7 (499) 37460-91. Эл. адрес: kvladimirm@mail.ru 
Kirillin Vladimir Mikhailovich, Doctor of Philology, Professor, Department of Journalism, Moscow University for the Humanities. Postal address: 5 Yunosti St., 111395 Moscow, Russian Federation. Phone: +7 (499) 374-60-91. Эл. адрес: kvladimirm@mail.ru 